\title{
Prevalence of Atrial Fibrillation in Spain: OFRECE Study Results
}

\author{
Juan José Gómez-Doblas, Javier Muñiz, Joaquín J. Alonso Martin, Gustavo Rodríguez- \\ Roca, José Maria Lobos, Paula Awamleh, Gaietá Permanyer-Miralda, Francisco Javier \\ Chorro, Manuel Anguita, Eulalia Roig, on behalf of the OFRECE study collaborators
}

\begin{abstract}
Introduction and objectives. Atrial fibrillation is associated with substantial morbidity and mortality and both its incidence and prevalence are high. Nevertheless, comprehensive data on this condition in Spain are lacking. The aim of this study was to estimate the prevalence of atrial fibrillation in Spain.

Methods. A cross-sectional study was conducted in the general Spanish population older than 40 years. Two-stage random sampling was used, in which first-stage units were primary care physicians randomly selected in every Spanish province and second-stage units were 20 randomly selected persons drawn from each participating physician's assigned population. The reported prevalence was standardized for the age and sex distribution of the Spanish population. The electrocardiogram recordings were read centrally.

Results. Overall, 8343 individuals were evaluated. The mean age was 59.2 years (95\% confidence interval, 58.6-59.8 years), and $52.4 \%$ of the participants were female. The overall age-adjusted prevalence of atrial fibrillation was $4.4 \%$ (95\% confidence interval, 3.8-5.1). Prevalence was similar in both sexes, men 4.4\% (3.6-5.2) and women 4.5\% (3.65.3), rising with increasing age older than 60 years. In patients older than 80 years, the prevalence was $17.7 \%$ (14.121.3). In $10 \%$ of patients an unknown atrial fibrillation was diagnosed.

Conclusions. The prevalence of atrial fibrillation in the general Spanish population older than 40 years is high, at $4.4 \%$. The prevalence is similar in both sexes and rises steeply above 60 years of age. It is estimated that there are over 1 million patients with atrial fibrillation in the Spanish population, of whom over 90000 are undiagnosed.

\section{Resumen}

Introducción y objetivos. La fibrilación auricular se asocia con elevadas morbilidad y mortalidad, y tanto su incidencia como su prevalencia son altas. No obstante, hay escasos datos poblacionales sobre su epidemiología en España. El objetivo de este estudio es estimar la prevalencia de fibrilación auricular en España.

Métodos. Estudio transversal en población española de 40 o más años. Se realizó un muestreo en dos etapas, una primera selección aleatoria de médicos de atención primaria de cada provincia española y, en segundo lugar, se seleccionó aleatoriamente a 20 individuos de la población asignada a cada médico participante. La prevalencia se ponderó por edad, sexo y área geográfica. Se realizó una lectura centralizada de los registros electrocardiográficos. Resultados. Se evaluó a 8.343 personas (media de edad, 59,2 [intervalo de confianza del 95\%, 58,6-59,8] años; el $52,4 \%$ mujeres). La prevalencia total de fibrilación auricular fue del 4,4\% (intervalo de confianza del 95\%, 3,8-5,1). La prevalencia fue similar en varones $(4,4 \%[3,6-5,2])$ y mujeres $(4,5 \%[3,6-5,3])$ y se incrementa progresivamente a partir de los 60 años de edad. En los mayores de 80 años, la prevalencia fue del 17,7\% (14,1-21,3). En un $10 \%$ de pacientes se diagnosticó una fibrilación auricular no conocida.

Conclusiones. La prevalencia de fibrilación auricular en la población general española mayor de 40 años es elevada, del 4,4\%. La prevalencia es similar en varones y mujeres y se incrementa escalonadamente a partir de los 60 años. Se estima en más de 1 millón de pacientes con fibrilación auricular en la población española, de los que más de 90.000 están sin diagnosticar.
\end{abstract}

Abbreviations

$\mathrm{AF}$, atrial fibrillation; $\mathrm{ECG}$, electrocardiogram; PC, primary care

Keywords

Atrial fibrillation; Prevalence; Epidemiology

Palabras clave

Fibrilación auricular; Prevalencia; Epidemiología 


\section{Introduction}

Atrial fibrillation (AF) is the most common arrhythmia in Western countries and is associated with high mortality and morbidity. ${ }^{1 \text { and } 2}$ It is the leading cause of embolic events and is also associated with episodes of heart failure, cognitive impairment, and decreased quality of life. ${ }^{3,4,5}$ and 6 The most common embolic event is stroke, which is associated with severe disability and dependence, involving significant increases in costs and in the use of health care systems. ${ }^{7}$ Identifying these patients is important because anticoagulation therapy is effective in preventing embolic events in patients at high risk. Study of the population prevalence of $\mathrm{AF}$, using homogeneous criteria, provides valuable information for planning appropriate strategies for the prevention and treatment of this disease. In Spain, there is a lack of epidemiological data that would allow the prevalence rates of AF to be determined in the general population. In general, previous studies were conducted in groups of patients or in selected populations that were not representative of the Spanish general population, such as patients from specific areas not representative of the whole country, patients attending health centers or cardiology clinics, which introduced bias, or patients within narrow age ranges. ${ }^{8,9,10}$ and 11

The aim of this population-based study was to estimate the prevalence of AF in the Spanish population older than 40 years by age (decades) and sex groups.

\section{Methods}

\section{Design and Definitions}

A cross-sectional study was conducted in primary care (PC) among the general Spanish population older than 40 years assigned to a PC physician. One hospital from each Spanish province (2 in the case of Barcelona and Madrid) was invited to participate in the study, as well as a referral cardiologist from each hospital. In total, 46 provinces and 47 hospitals and cardiologists participated. Four provinces and the second hospital in Madrid were excluded or did not participate due to a variety of logistic problems. Based on this, a 2-stage random sampling procedure was used.

In each hospital, the number of PC physicians and their assigned population was determined and the participating physicians were selected using simple random sampling. Ten PC physicians were selected from each hospital. Each cardiologist was responsible for coordinating the work of these 10 physicians in his or her center. At this time, the participating hospitals had almost 8000 PC physicians assigned to them. A further 769 physicians were invited to participate, of whom 425 (55.2\%) participated (Fig. 1).

For each participating PC physician, simple random sampling based on the national health card of the assigned population older than 40 years was performed, so that 20 patients were selected per physician. Selected individuals were invited to participate by the PC physician. At this stage, a 76\% $(n=8400)$ participation rate was achieved. All participants gave their informed consent to participate in the study. The study began in March 2010 and ended in October 2012.

Overall, 57 people were excluded due to the lack of key information $(n=4)$ or because the electrocardiogram (ECG) could not be evaluated $(n=53)$, and thus the final sample consisted of 8343 participants (Fig. 1).

All patients were examined by their PC physician, an ECG was performed on the day of the visit, and the patients were referred to the coordinating cardiologist for fast tracking according to the protocol (newly diagnosed or uncertain diagnosis). All ECGs were read centrally by at least 2 cardiologists (Fuenlabrada University Hospital) as described below. All the ECGs were initially evaluated by 1 cardiologist and subsequently by another cardiologist. If there was a discrepancy between the 2 diagnoses, a third cardiologist was consulted and a final diagnosis was reached by consensus between the second and third cardiologists. Of the total number of ECGs analyzed, a consensus was reached in $99.9 \%$ of the patients, of which $98.1 \%$ were classified as having AF (262 of 267) by 1 observer; thus, in $1.9 \%$ of the patients, there was disagreement between the 2 cardiologists who specifically analyzed the ECGs for the presence of AF. In total, the 15 patients who were not diagnosed during their examination by the PC physician were diagnosed when their ECGs were read centrally. These diagnoses were reported to the PC physicians in order for them to take any appropriate action. 


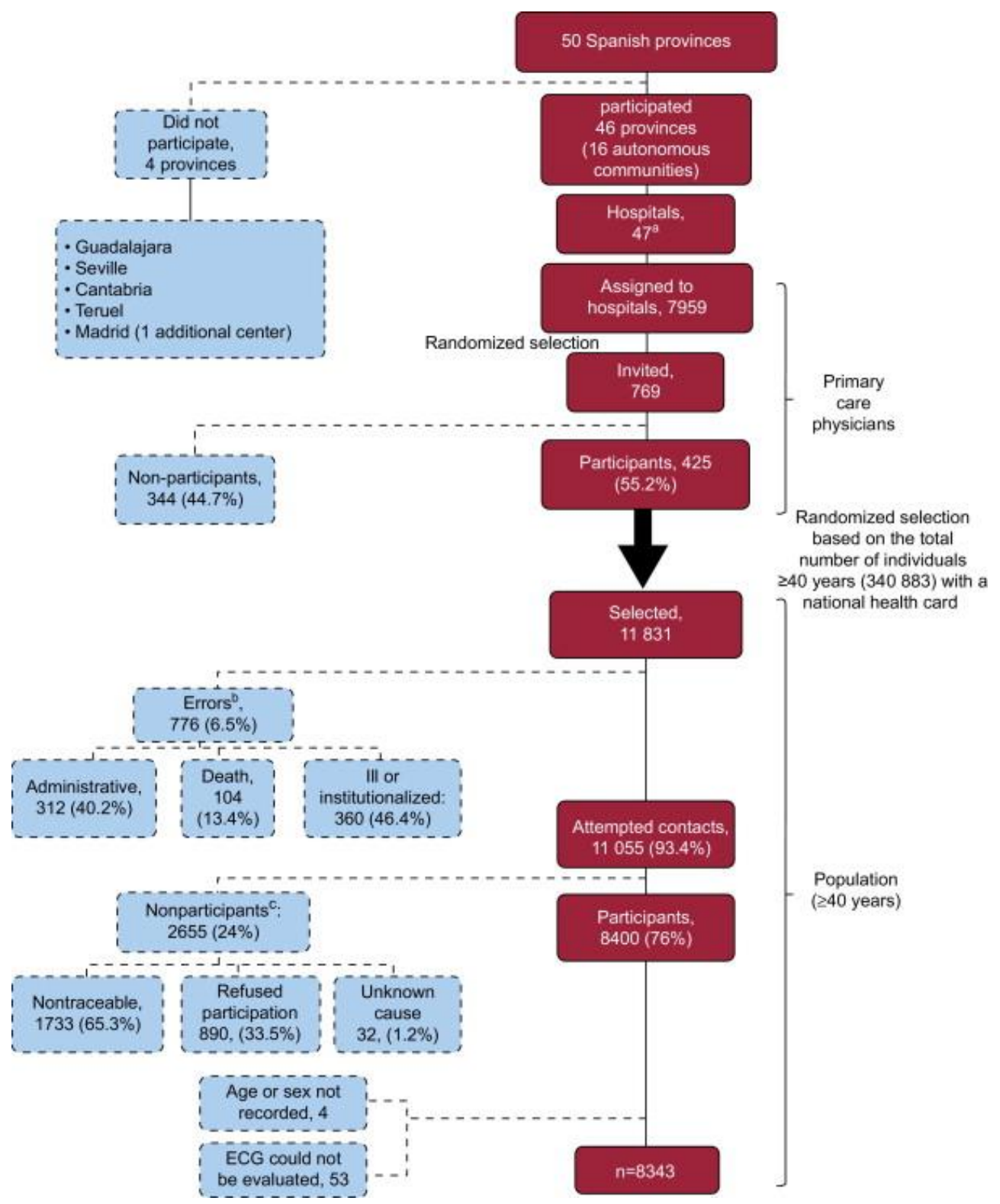

Figure 1. Flowchart of participation in the OFRECE study. ECG, electrocardiogram.

${ }^{a}$ Barcelona: 2 hospitals participated. ${ }^{b}$ Errors. Administrative: no longer a patient of the physician (does not belong to the center or the quota assigned), language difficulty; ill or institutionalized: institutionalized, acute or chronic disease preventing visits to the center, hospitalization, terminal process, bedridden, dementia, Alzheimer disease, mental disability, mental retardation or cognitive impairment. ${ }^{\circ}$ Reasons for not participating. Unreachable: after repeated attempts to contact by mail and/or telephone; participant refusal: refusal to participate or initial acceptance but failure to attend the center, various personal or business reasons preventing attendance at the center; unknown: unspecified cause.

Information on demographic variables, personal details, and general variables were collected, as well as clinical variables using a specific questionnaire for AF. The various clinical variables were defined according to the guidelines of the American College of Cardiology/American Heart Association for $\mathrm{AF}^{12}$ as follows: obesity, body mass index greater than or equal to 30; overweight, body mass index greater than or equal to 25; central obesity, waist circumference greater than or equal to $102 \mathrm{~cm}$ for men and greater than or equal to $88 \mathrm{~cm}$ for women; hypercholesterolemia, previous diagnosis and treatment with lipid-lowering drugs; diabetes mellitus, previous diagnosis and treatment with oral diabetic agents or insulin; and previous diagnosis of documented ischemic heart disease, such as previous myocardial infarction, unstable angina or revascularization. Hypertension was defined as the presence of any of the following criteria: $a$ ) previous diagnosis of hypertension and treatment with medication, diet or exercise, and $b$ ) systolic blood pressure greater than or equal to $140 \mathrm{mmHg}$ or diastolic blood pressure greater than or equal to $90 \mathrm{mmHg}$ on at least 2 occasions on the day of examination. 
A diagnosis of AF was based on 2 criteria: a) the presence of AF on ECG performed on the day of examination, and/or $b$ ) a documented clinical history of nonpermanent AF (paroxysmal or persistent).

\section{Statistical Analysis}

Given the nature of the sampling process, in which individuals in the population had different probabilities of being selected, each participant in the final sample was assigned a weight representing the number of people in the Spanish population (with the exception of Ceuta, Melilla, and Cantabria, which did not provide participants), for the same age, sex, and geographical area as those represented by the patient. ${ }^{13}$ Thus, the sum of all the weights of the sample was equal to the size of the Spanish population older than 40 years.

Weighting was done in 2 stages. In the first stage of the 2-stage sampling design, the weights were calculated as the inverse of the probability of selecting each individual in each stage of the sampling process. In the first stage (physician selection), the probability of selection in each province was calculated by using the number of PC physicians in the province as the denominator. In the second stage (participant selection), the number of people older than 40 years assigned to each physician was used as the denominator. In the second stage, a reweighting procedure was performed to adjust the sample distribution to the population distribution for variables related to the outcome of the analysis and not considered in the sampling procedure (age and sex). A third variable (geographical area) was included in case it was decided to present the data disaggregated by area. The data by autonomous community was not presented because the sample size calculated would provide inaccurate estimates. The reweighting procedure was performed using the method proposed by Deville and Särndal ${ }^{14}$ using the calibrate instruction in the Stata v10.1 statistical software package. The municipal population census of 2011 was used to adjust or calibrate for sex, age, and geographic area. We considered 5 geographic areas defined by autonomous community grouping: north (Aragón, Principality of Asturias, Galicia, Chartered Community of Navarre, Basque Country, La Rioja); central (Castile and León, Castile-La Mancha, Community of Madrid); east (Catalonia, Valencian Community, Region of Murcia, Balearic Islands); south/south-West (Andalusia, Extremadura); and the Canary Islands.

All the analyses took into account the sampling design of the study. In the case of AF, specific prevalences were calculated by age and sex, as well as total prevalence and their $95 \%$ confidence intervals $(95 \% \mathrm{CI})$.

Age- and sex-adjusted odds ratios were estimated using logistic regression models in order to identify cardiovascular risk factors and antecedents associated with the presence of AF. Subsequently, a multivariate model was adjusted for the variables with $P<.01$ in the bivariate analysis

\section{Results}

The study included 8343 participants (mean age, 59.2 [95\%CI, 58.6-59.8] years; 52.4\% women). Table 1 shows the general characteristics of the study population and, for purposes of comparison, the same population disaggregated into those with a diagnosis of $\mathrm{AF}$ and those without AF. In the study population, AF was diagnosed in 410 patients (204 men and 206 women). Of these, 267 had a diagnosis of AF on ECG on the day of examination. The remaining 143 patients had a documented history of AF but did not have $\mathrm{AF}$ on the day of examination (nonpermanent $\mathrm{AF}, 34.9 \%$ of all patients with $\mathrm{AF}$ ). 
Table 1. Characteristics of the Population With and Without Atrial Fibrillation

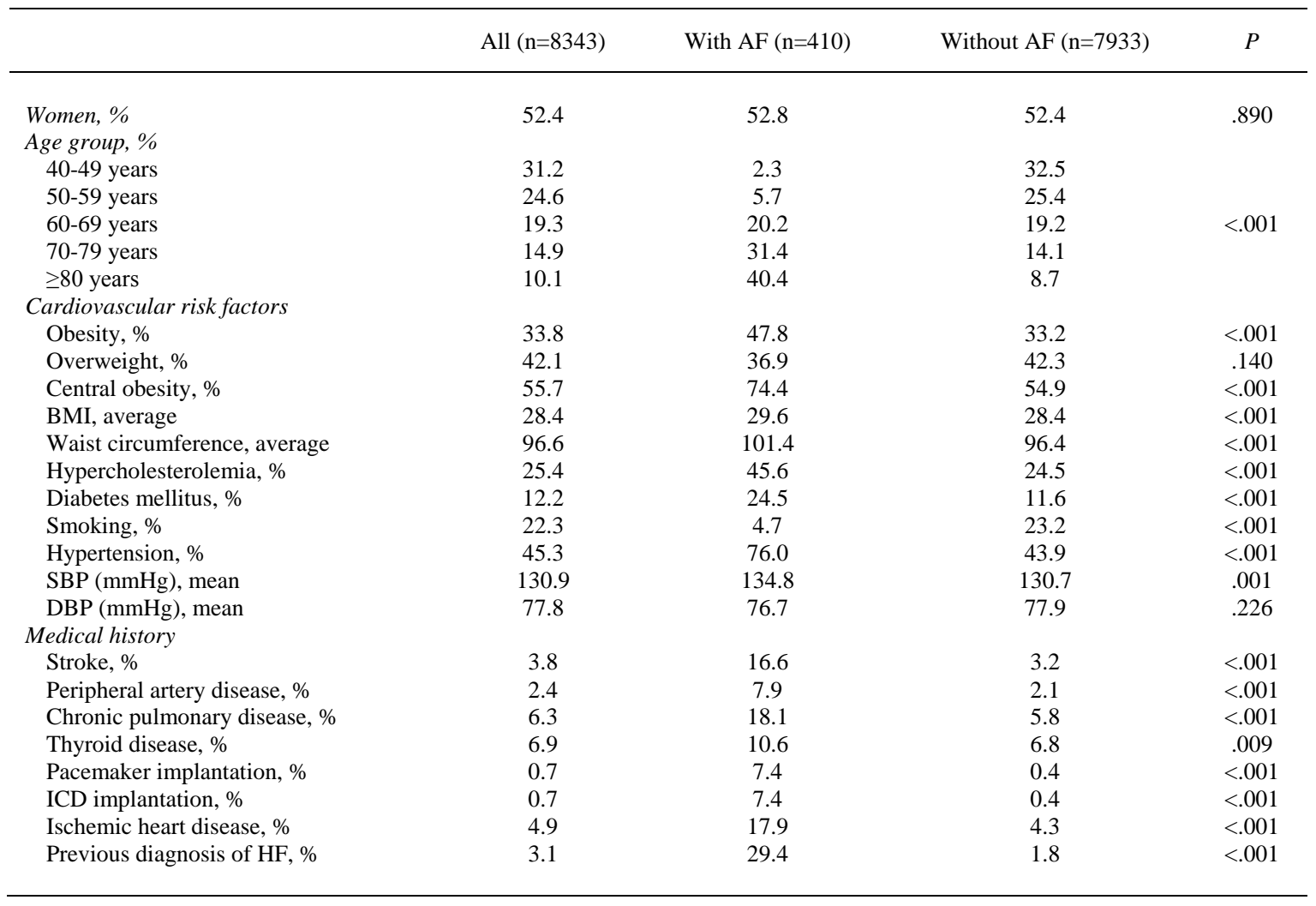

AF, atrial fibrillation; BMI, body mass index; DBP, diastolic blood pressure; HF, heart failure; ICD, implantable cardioverterdefibrillator; SBP, blood pressure.

The overall prevalence of $\mathrm{AF}$ was $4.4 \%$ (95\% CI, 3.8-5.1). The prevalence was similar in men $(4.4 \%$ [3.6-5.2]) and women (4.5\% [3.6-5.3]), rising with increasing age older than 60 years. The prevalence of AF by age and sex is presented in Table 2 and Figure 2. 
Table 2. Prevalence of Atrial Fibrillation by Sex and Age Group and Estimated Number of Patients in the Spanish Population

\begin{tabular}{|c|c|c|c|c|c|c|}
\hline \multirow[b]{2}{*}{ Age } & \multicolumn{2}{|c|}{ Men $(n=3829)$} & \multicolumn{2}{|c|}{ Women $(n=4514)$} & \multicolumn{2}{|c|}{ Total $(\mathrm{n}=8343)$} \\
\hline & $\%$ & $95 \% \mathrm{CI}$ & $\%$ & $95 \% \mathrm{CI}$ & $\%$ & $95 \% \mathrm{CI}$ \\
\hline $40-49$ years & 0.5 & $0.0-1.2$ & 0.2 & $0.0-0.4$ & 0.3 & $0.0-0.7$ \\
\hline $50-59$ years & 0.9 & $0.3-1.6$ & 1.1 & $0.1-2.1$ & 1.0 & $0.4-1.7$ \\
\hline $60-69$ years & 5.3 & $3.1-7.5$ & 4.0 & $2.3-5.7$ & 4.6 & $3.4-5.9$ \\
\hline $70-79$ years & 11.9 & $8.9-14.9$ & 7.2 & $5.1-9.3$ & 9.3 & $7.4-11.2$ \\
\hline$\geq 80$ years & 17.0 & $11.9-22.1$ & 18.1 & $13.3-22.9$ & 17.7 & $14.1-21.3$ \\
\hline Total & 4.4 & $3.6-5.2$ & 4.5 & $3.6-5.3$ & 4.4 & $3.8-5.1$ \\
\hline Age & $\begin{array}{c}\text { Total } \\
\text { (in thousands) }\end{array}$ & $95 \% \mathrm{CI}$ & $\begin{array}{c}\text { Total } \\
\text { (in thousands) }\end{array}$ & $95 \% \mathrm{CI}$ & $\begin{array}{c}\text { Total } \\
\text { (in thousands) }\end{array}$ & $95 \% \mathrm{CI}$ \\
\hline $40-49$ years & 17.3 & $0.0-43.6$ & 6.30 & $0.0-14.0$ & 23.6 & $0.0-50.9$ \\
\hline $50-59$ years & 26.7 & $9.26-44.2$ & 31.6 & $0.49-62.6$ & 58.3 & 21.4-95.2 \\
\hline $60-69$ years & 114.6 & $64.6-164.7$ & 92.7 & $52.1-133.3$ & 207.4 & $145.3-269.4$ \\
\hline $70-79$ years & 183.0 & $131.8-234.1$ & 138.9 & $97.5-180.3$ & 321.8 & $252.9-390.9$ \\
\hline$\geq 80$ years & 142.3 & 99.9-184.7 & 272.4 & $193.8-351.1$ & 414.7 & $326.2-503.3$ \\
\hline Total & 483.9 & $394.9-572.9$ & 541.9 & $437.4-646.5$ & 1025.8 & $879.1-1172.6$ \\
\hline
\end{tabular}

95\% CI, 95\% confidence interval.

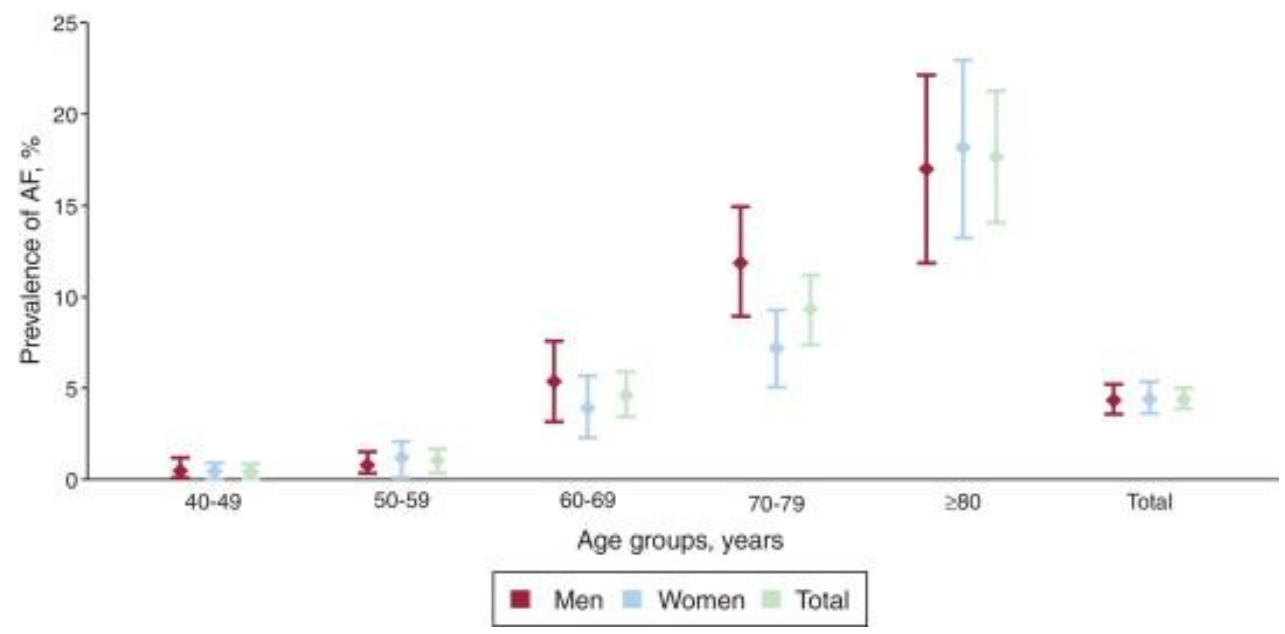

Figure 2. Prevalence of atrial fibrillation by sex and age group (95\% confidence intervals). AF, atrial fibrillation.

Regarding cardiovascular risk factors, patients with AF had a higher percentage of obesity (47.8\% vs $33.2 \% ; P<.001)$, hypercholesterolemia $(45.6 \%$ vs $24.5 \% ; P<.001)$, diabetes mellitus $(24.5 \%$ vs $11.6 \%$; $P<.01)$, and hypertension $(76 \%$ vs $43.9 \% ; P<.01)$, and a lower percentage of smoking $(4.7 \%$ vs $23.2 \%$; $P<.001)$ than patients without AF. Patients with AF more often had a history of cerebrovascular disease (16.6\% vs $3.2 \% ; P<.001)$, peripheral arterial disease $(7.9 \%$ vs $2.1 \% ; P<.001)$, pulmonary disease $(18.1 \%$ vs $5.8 \% ; P<.001)$, ischemic heart disease $(17.9 \%$ vs $4.3 \% ; P<.001)$ and a history of heart failure $(29.4 \%$ vs $1.8 \% ; P<.001$ ) ( Table 1 ).

Multivariate analysis showed that age, male sex, central obesity, not smoking, a history of heart failure, thyroid disease, and having a pacemaker were independently associated with the presence of AF (Table 3). Although no differences were found in the prevalence of AF by sex, differences were found by decade, with a higher prevalence in men less than 80 years of age and in women more than 80 years of age. These data are in line with those of other studies, except for the finding of a higher prevalence in women in their eighties. Of the 410 patients with AF, $41(10 \%)$ were diagnosed on the day of the examination (unknown AF). 
Table 3. Age- and Sex-adjusted Odds Ratios of Having Atrial Fibrillation for Each Cardiovascular Risk Factor, Previous History, and Final Multivariate Model

\begin{tabular}{lcc}
\hline & OR (95\%CI) & $P$ \\
\hline & & \\
Cardiovascular risk factors & & .001 \\
Obesity & $1.65(1.22-2.23)$ & .038 \\
Overweight & $0.71(0.51-0.98)$ & $<.001$ \\
Central obesity & $1.78(1.32-2.40)$ & .004 \\
Hypercholesterolemia & $1.60(1.17-2.19)$ & .032 \\
Diabetes mellitus & $1.42(1.03-1.94)$ & .012 \\
Smoking & $0.44(0.23-0.83)$ & .029 \\
Hypertension & $1.55(1.05-2.29)$ & .042 \\
Previous history & & .005 \\
Peripheral artery disease & $1.81(1.02-3.21)$ & .002 \\
Chronic pulmonary disease & $1.88(1.21-2.92)$ & $<.001$ \\
Thyroid disease & $1.90(1.27-2.85)$ & $<.001$ \\
Pacemaker & $9.31(4.76-18.22)$ & $<.001$ \\
Ischemic heart disease & $2.59(1.68-4.00)$ & $<.001$ \\
Previous diagnosis of HF & $8.73(5.27-14.45)$ & .005 \\
Multivariate model & & .001 \\
Age & & .028 \\
Female sex & $1.08(1.06-1.10)$ & .016 \\
Central obesity & $0.61(0.43-0.86)$ & .001 \\
Smoker & $1.70(1.24-2.33)$ & $<.001$ \\
Thyroid disease & $0.47(0.24-0.92)$ & $1.69(1.11-2.58)$ \\
Pacemaker & $5.50(2.11-14.36)$ & $7.72(4.44-13.41)$ \\
\hline
\end{tabular}

95\%CI, 95\% confidence interval; HF, heart failure; OR, odds ratio.

Table 4. Characteristics of the Population With New Atrial Fibrillation and Previously Diagnosed Atrial Fibrillation

\begin{tabular}{|c|c|c|c|}
\hline & New AF & Known AF & $P$ \\
\hline Participants, no. & 41 & 369 & \\
\hline \multicolumn{4}{|l|}{ Sex $\%$} \\
\hline Men & 59.8 & 45.9 & .208 \\
\hline Women & 40.2 & 54.1 & \\
\hline Age (years), mean & 74.7 & 75.3 & .782 \\
\hline \multicolumn{4}{|l|}{ CVRF,$\%$} \\
\hline Obesity & 40.0 & 48.6 & .401 \\
\hline Overweight & 51.1 & 35.4 & .101 \\
\hline Central obesity & 73.9 & 74.5 & .942 \\
\hline Hypercholesterolemia & 42.3 & 45.9 & .708 \\
\hline Diabetes mellitus & 9.8 & 26.0 & .016 \\
\hline Smoking & 17.9 & 3.3 & .004 \\
\hline Hypertension & 77.1 & 75.9 & .907 \\
\hline \multicolumn{4}{|l|}{ Medical history, $\%$} \\
\hline Stroke & 17.9 & 16.5 & .851 \\
\hline Peripheral artery disease & 7.4 & 8.0 & .911 \\
\hline Chronic pulmonary disease & 10.6 & 18.9 & .227 \\
\hline Thyroid disease & 7.1 & 11.0 & .494 \\
\hline Pacemaker & 4.8 & 7.7 & .473 \\
\hline Ischemic heart disease & 23.5 & 17.3 & .397 \\
\hline Previous diagnosis of $\mathrm{HF}$ & 7.4 & 31.6 & .007 \\
\hline \multicolumn{4}{|l|}{ Previous visit for dizziness/palpitations, $\%$} \\
\hline Previous visit & 25.3 & 55.7 & .007 \\
\hline Visit to PC physician & 25.3 & 41.8 & .476 \\
\hline Visit to the cardiologist & 7.8 & 43.0 & .036 \\
\hline Visit to hospital emergency service & 9.6 & 37.1 & .284 \\
\hline
\end{tabular}

$\mathrm{AF}$, atrial fibrillation; $\mathrm{CVRF}$, cardiovascular risk factors; $\mathrm{HF}$, heart failure; $\mathrm{PC}$, primary care. 
The Spanish 2011 census estimated the population to be 46815916 inhabitants; of these, $51.1 \%$ (23922 933 people) were older than 40 years of age. By applying the specific prevalences for age and sex observed in the OFRECE study to the Spanish population, and taking into account the design, the number of patients with $\mathrm{AF}$ in the population older than 40 years in Spain (with the exception of Cantabria, Ceuta, and Melilla) was estimated to be 1025846 (95\%CI, 879 077-1 172 614), of whom 94546 (95\%CI, 57 944-131 148) would be undiagnosed.

\section{Discussion}

This study is the first to provide estimates of the prevalence of AF in the Spanish population older than 40 years of age and shows that the prevalence of AF in this population increases with age. The strength of this study lies in the fact that it was conducted using the general population and that a highly representative sample was obtained by the random selection of PC physicians and the population assigned to each physician, thereby strengthening the validity of the results. Previous studies have been based on the records of patients with other cardiovascular diseases (eg, hypertension) or on specific geographical areas, which has led to widely varying estimates, with prevalences between $0.7 \%$ and $8.5 \%$., ${ }^{8,10}$ and 11 The REGICOR study, ${ }^{9}$ the only study conducted in the general population rather than in patients from different areas, found a prevalence of $0.7 \%$. However, that study was strongly limited by its exclusion of the population older than 74 years of age, precisely the age group with the highest prevalence of AF. In the PREV-ICTUS study, ${ }^{10}$ a population-based cross-sectional study that analyzed participants older than 60 years, the prevalence of $\mathrm{AF}$ was $8.5 \%$ (95\% CI, 7.9\%-9.2\%), was higher in men (9.3\% vs $7.9 \%$ in women), and increased from $4.2 \%$ in those aged between 60 and 64 years to $16.5 \%$ in those older than 85 years. The CARDIOTENS study, ${ }^{8}$ which was conducted in hypertensive patients, found a prevalence of $\mathrm{AF}$ of $4.8 \%$, which increased with each decade of life (1.0\% in those younger than 50 years and $11.1 \%$ in those older than 80 years). However, CARDIOTENS cannot be considered a population-based study because it included consecutive patients attending PC centers or cardiology services, which could have led to a selection bias that overestimated prevalence.

European studies have also reported wide variability in prevalences in the general population, with estimates ranging from $0.2 \%$ to $1.2 \%$ and, for people older than 50 years of age, from $1.5 \%$ to $5.5 \%$., 15 , 16, 17, 18 and 19 Most of the studies that have investigated the prevalence of AF are not strictly comparable for 2 reasons: $a$ ) the characteristics of the study population and their distribution by age and sex, and $b$ ) the method used to diagnose AF. Studies that based the diagnosis of AF on ECG alone, and not on a history of AF, found lower prevalences than those that based the diagnosis on ECG and a clinical history of AF. ${ }^{15}$ Another aspect that may influence the prevalence of AF in different series, as confirmed in this study, is the risk profile of the populations analyzed (prevalence of hypertension, diabetes mellitus, obesity, etc). In the case of the Spanish population, recent studies have demonstrated a high prevalence of variables associated with $\mathrm{AF}$, which are not always well adjusted. ${ }^{20 \text { and } 21}$ In this study, all ECGs were read centrally by 2 cardiologists, which increased the quality of the information by enhancing diagnostic certainty and reducing variability and misclassification problems.

Interestingly, $10 \%$ of patients with $\mathrm{AF}$ at the time of examination were unaware of having $\mathrm{AF}$. This figure is slightly different from that described by Labrador et al. ${ }^{11}$ or Wheeldon et al., ${ }^{16}$ who found that $8.6 \%$ and $7.7 \%$ or more of patients had undiagnosed AF, respectively. However, both these studies only analyzed the general population aged 65 years and older, and therefore the data are not directly comparable. ${ }^{11 \text { and } 16}$ It should be noted that there were higher percentages of men, patients without diabetes, smokers, and patients without a history of heart failure in the population of patients with previously undiagnosed AF (an arrhythmia that may cause few symptoms). This finding is very important because patients with AF have a 5-fold higher risk of a stroke ${ }^{22}$ and because effective treatment is available using classical or novel anticoagulants to prevent these embolic events. ${ }^{23}$ and 24

\section{Limitations}

The hospitals studied within each province were not randomly selected. This probably had very little impact on the study as it is unlikely that the prevalence of AF varies significantly between adjacent areas. Of more importance, the randomized selection of the physicians and particularly of the patients assigned to each physician was considered to add strength to the results of this study. The high number of sampling points improved the representativeness of the sample, which is sometimes difficult to evaluate. A limitation inherent to this type of general population study is that the participants may differ from nonparticipants. Although it is impossible to completely rule out potential bias due to selective participation and to determine its direction, it should be emphasized that any such bias cannot be very 
large, since there was a very good participation rate for this type of study (76\% of those invited to participate in the study) and, of the nonparticipants, only one-third did not participate due to refusal. Another limitation is that the patients without a known history of paroxysmal AF and with a normal ECG at the time of examination by the family physician were not diagnosed with AF; however, this limitation is common to all published studies on the prevalence of AF and is difficult to avoid. Furthermore, when AF was diagnosed on the basis of clinical history alone, a centralized reading of the previous ECG was obviously not possible; nevertheless, a diagnosis of AF was only included in the study if such a reading was recorded in a medical record or the clinical history in PC.

\section{Conclusions}

The prevalence of AF in the general Spanish population older than 40 years is high (4.4\%). The overall prevalence is similar in men and women, but differs according to the decade of age analyzed and increases steeply above 60 years of age. There are over 1 million patients with AF in the Spanish population, of whom more than 90000 are undiagnosed. This has important implications for public health due to the frequency and severity of complications caused by this arrhythmia in the absence of treatment.

\section{Funding}

The OFRECE study was supported by the Research Agency of the Spanish Society of Cardiology (Agencia de Investigación de la Sociedad Española de Cardiología). This study was made possible by financial support from SANOFI, which was not involved in the study design, data analysis, or preparation of the final manuscript, and partly (pilot study) by the Observatorio de Salud de la Mujer, the Observatorio del Sistema Nacional de Salud, the Agencia de Calidad del Sistema Nacional de Salud, and the Ministerio de Salud y Consumo.

\section{Conflicts of interest}

None declared.

\section{Acknowledgements}

The authors acknowledge the assistance of the Steering Committee, coordinators, researchers and collaborators listed in the Appendix, and the following institutions which contributed to the development of the study: Consejería de Salud de la Junta de Andalucía; Servicio Aragonés de Salud, Gobierno de Aragón; Consejería de Sanidad del Principado de Asturias; Servicio de Salud de Castilla-La Mancha; Consejería de Sanidad de la Junta de Castilla y León; Conselleria de Salut de la Generalitat de Catalunya; Conselleria de Sanitat de la Generalitat Valenciana; Consejería de Sanidad, Gobierno de Extremadura; Consellería de Sanidade de la Xunta de Galicia; Conselleria de Salut i Consum, Gobern de les Illes Balears; Consejería de Sanidad, Gobierno de Canarias; Consejería de Sanidad, Gobierno de la Rioja; Consejería de Sanidad de la Comunidad de Madrid; Consejería de Sanidad y Política Social, Región de Murcia; Consejería de Sanidad, Gobierno de Navarra, and Consejería de Sanidad del Gobierno Vasco. We also thank ODDS S.L. as the coordinating center and for data analysis. We also extend special thanks to Soly Santiago Perez, for data analysis, Teresa Rosalía Perez Castro, for managing the database, training the participating physicians, and coordinating work field, and M. Luisa López Domínguez, for her administrative work and call-center coordination. 
Appendix. Steering Committee, coordinators, researchers, collaborators, and reading center

\section{Steering Committee}

Executive Committee

Juan José Gómez-Doblas, Servicio de Cardiología, Hospital Clínico Universitario Virgen de la Victoria, Málaga; Javier Muñiz, Instituto de Ciencias de la Salud, Universidad de A Coruña, A Coruña; Joaquín J. Alonso Martín, Servicio de Cardiología, Hospital Universitario de Fuenlabrada, Fuenlabrada, Madrid; Eulalia Roig, Servicio de Cardiología, Hospital de Sant Pau, Barcelona

Scientific Committee

Gustavo Rodríguez-Roca, Centro de Salud La Puebla de Montalbán, Toledo; José Maria Lobos, Centro de Salud Villablanca, Madrid; Gaietá Permanyer, Servicio de Cardiología, Hospital Universitari Vall d'Hebron, Barcelona; Manuel Anguita, Servicio de Cardiología, Hospital Reina Sofía, Córdoba

Coordinators, researchers and collaborators

\begin{tabular}{|c|c|c|c|}
\hline \multirow{5}{*}{ Andalusia } & Córdoba & Manuel Anguita Sánchez & $\begin{array}{l}\text { Emilio García Criado; Jorge Martínez de la Iglesia; Juana Redondo } \\
\text { Sánchez; Enrique Martín Rioboo; Juana María González Barranco; } \\
\text { Francisco Javier Ruiz Moruno; María Auxiliadora Cabanás Espejo; } \\
\text { Trinidad Lechuga Varona; Cristina Aguado Taberne; Juan José } \\
\text { García Gallego. Collaborators: Antonia Calero Espino }\end{array}$ \\
\hline & Granada & Pablo Toledo Frías & $\begin{array}{l}\text { Nieves Hitos Henares; Rosario López Bueno; Adoración Caba } \\
\text { Martín; Concepción Molina Serrano; Concepción Macía Canon; } \\
\text { Pedro Tejeda Paredes; Antonieta Maldonado Larroque. } \\
\text { Collaborators: Amparo Arrabal Martín, Agustina Matilla Marcos }\end{array}$ \\
\hline & Huelva & Carlos Sánchez González & $\begin{array}{l}\text { Antonio Ortega Carpio; M. Eloisa Arias Fortes; Javier Ferraro } \\
\text { García; Migliane Lima Costa; Isabel Ruiz Cumplido; Pilar Freire } \\
\text { Pérez }\end{array}$ \\
\hline & Jaén & $\begin{array}{l}\text { Eduardo Vázquez Ruiz de } \\
\text { Castroviejo }\end{array}$ & $\begin{array}{l}\text { Ramiro Aguilera Tejero; Fermina Bruque Sánchez; Pablo Tallón } \\
\text { Povedano; Lorenzo Escabias Andreu; Víctor Figueroa Cardona; } \\
\text { Alejandro Pérez Milena; José Moraleda Martínez; M. Dolores } \\
\text { Rodríguez Serrano }\end{array}$ \\
\hline & Seville & & Antonio Casco Gallardo \\
\hline \multirow[t]{2}{*}{ Aragón } & Huesca & $\begin{array}{l}\text { Javier Escota Villanueva; } \\
\text { Mariano Rodríguez } \\
\text { Torrente }\end{array}$ & $\begin{array}{l}\text { Eva Aguaron Joven; José María Borrel Martínez; Juan Manuel } \\
\text { Culebras Marco; Dolores Idañez Rodríguez; Teófilo Lorente } \\
\text { Aznar; Ana Rivera Fuertes; Carmen Quintana Velasco; Carlos Aisa } \\
\text { Arenaz; José María Barrio Navascues; José María Castillo Olivera. } \\
\text { Collaborators: Inmaculada Lera Omiste, Gemma Ciria }\end{array}$ \\
\hline & Zaragoza & Ricardo Gayán & $\begin{array}{l}\text { Ana Avelino Terrón; M. Luisa Aznar Arribas; Pedro J. Marín } \\
\text { Velázquez; Adolfo Benito Jiménez; Rafael Vargas Arévalo; José } \\
\text { Fernando Pina; Jesús Fco. Romeo Ladrero; M. Asunción Alfaro } \\
\text { Lozano; José Javier Calvo García; Jesús María Lasso Moreno }\end{array}$ \\
\hline Principality o & Asturias & Inés Möller Bustinza & M. Teresa Saldaña Hernández; Manuel Berrocal Varela; Amador \\
\hline
\end{tabular}


Asturias

Castile-La Mancha

Castile and

León
Albacete

Moisés Barambio Ruiz

Ciudad Rea

Luis Ruiz-Valdepeñas Herrero

Cuenca

Antonio Melero Pita

Toledo

Luis Rodríguez Padial

Burgos

Germán Pérez Ojeda

Leon

Palencia

Chema Asín Guillén

Salamanca

Javier Jiménez Candil

Segovia

Carlos Junquera Planas

Soria

Valladolid

María Jesús Rollán Gómez
Jenaro Carbajal Cocina; Francisco Javier Claros González; Natalia Juesas Fernández; Joaquín Prieto Gutiérrez; Agustín Sánchez Hernández; Purificación Seijo González; Ana Picasso Martínez de Ubago

Antonio Cifuentes Verdú; Concepción Escolano Vizcaíno; Francisco Javier Ayllón Ayllón; Francisco Lorenzo Salido; Cándido Martínez García; María Concepción Casado Moragón; Antonio Martínez Lozano; Lucinio Carrión Valero; José Miguel Ocaña López; Mirian Martínez Carretero

Raquel Bañón García; M. Teresa Alcaide Cornejo; Cristina Herráiz Serrano; Antonio Guindas Ruiz; Andrés Herrera Canales; AntonioLorenzo Ruiz Serrano; Francisco de Asís Asenjo Hernández; Angel Fermín Pérez Sánchez; Alfonso Ruiz-Póveda García-Rojo; M. Isabel Ariza Sánchez

Isidro Sanz Polo; Rafael Morilla Ramilo; Joaquín Román López Villar; Fernando Madero López; Alfredo Cabrejas Sánchez; Rosa M. Cejudo Serrano; Jesús Buendía Bermejo; Sagrario Saiz Santos; Adoración Romero Saiz; Julia Martín Lezana

Raquel Parejo Míguez; José Ignacio Jaén Díaz; Angel Alonso Alía; Alberto Sepúlveda Martín; María Vega Martínez Escudero; Migue Laborda Peralta; José María Jiménez Rodríguez; M. Angeles Adán Valero; Francisco Javier Alonso Moreno; Carmen Ramos López. Primary care collaborators: Irene Martínez Giner, Jesús Adrián Sifuentes Hernández, María Dolores Martínez Malabia, Victoria Madiedo Acosta

Miguel Angel Fernández Gutiérrez; Carlos de Cabo González; Lidia Sastre Jiménez; F. Javier Ríos Almarza; Blanca Noreña Delgado; Cesarina Rivas Hernández; Carlos Javier García Gómez; Juan Luis Martín Clavo; Alfonso Carlos Caro Picón; Benigno Sánchez Martín

Angel María Olea Movilla; Pedro Luis Estables Recansens; Lucinio Anaya Bernabe; Carmen Caballero Abad; Jesús García Cuadrillero; M. Felisa Lara Caballero; Benito Sanz Mozo; Felipe Eulalio Martín Rosón; M. Cruz González González

Leonor Martín Santín; M. Isabel Fernández Marassa; Mercedes García de Celis; Elena Fernández Mielgo; Faustino Sánchez Sanmartino; Margarita Gallego de la Varga; Angel Novoa Mato; Ana Isabel Barragán Marín; Jesús Marino Villamar Berceruelo

Juan Antonio Losmozos Sánchez; José Luis Durand Eguiluz; María Carmen Monge González; Enrique de Inés Martín; José Manuel Zumel Elices; Juan Manuel Durantez Cacharro; Tomás Manzano Benito; Isaac Alcalde García; M. Eugenia Barón Laguna

Javier García Izquierdo; Julio Guerrero del Olmo; Luis García Ortiz; Carlos Hernán-Pérez Leal; José Calama Becerro; Carmen de Antonio Jiménez; Manuel Becerro Cereceda

Emilio García Ortega; Rosa María Fernández Santa Teresa; M. Concepción Manrique de la Fuente; Juan Francisco Gil García; Martín Merino Segovia; Fernando Mondejar Quirós; Javier González Perlado; Ana Isabel Herrero Cecilia; José de Pablo Álamo

M. Jesús de Pablo Ramos; Ana M. Cabrerizo Puente; M. Antonia Hernández Caballero; Antonio Alberto Gil Gómez; Francisco Javier Martínez Sanz; Luis Gutiérrez Moreno; Elena de Pablo Ramos; Ramón García Martínez; Angel Lafuente Esteban; Gema Borque Molinos

Rocio Velasco Pastor; M. Jesús Aller de la Fuente; Mercedes Redondo Valdeolmillos; Jesús María Aguilar García; Verónica Casado Vicente; Elpidio García Ramón; Luis Angel Herrán Oteruelo; Jesús Francisco García Rodríguez; Enrique Sanz Monedero; Ruperto Sanz Cantalapie Collaborator: Miguel Angel Morales Torres

Angela Nistal Ramos; Francisco Javier Delgado Rodríguez; Luis Garrote Gutiérrez; Antonia Refoyo Enríquez; M. Dolores 
José Javier Gómez Barrado

Galicia

José Angel Rodríguez Fernández

Lugo

Ourense

Manuel García García

Pontevedra

Francisco Calvo Iglesias
Rodríguez Martín; Pedro Martín Martín; Clodoaldo Pérez Ramos; Mercedes Prieto Mantellán; Gabriel González Panero; Alberto Jiménez Meléndez

Sandra Sabarich Flores; Judit Novo Salvador; Montserrat Llordés Llordés; María Eugenia Pérez Domínguez; Telma Cristina Vicentín; Francisco Javier Martínez Quílez; Francisco Javier Avilés Fernández; Laura Diaz Gete; Alicia Mostazo Muntané; Amelia Espinosa Santana; Antonia Llauger Roselló; M. Dolor Moriano García; Jordi Nadal Echevarria; M. Angels Salvador Millán; Herminio Moliner Lizondo. Collaborator: Monserrat Roca Vilalta

Josep Gil Yubero; Ferrán Cordón Granados; Montse Lloveras Clos; Emili Marco Segarra; Ramón Creus Bosch; Carmen López Sanmartín; Dídac Parramón i Font; Begoña Santana de Carlos; Cristina Servent Batlle. Collaborators: Judith Pinsach Garanger, Laura Vegas Fernández

Jorge Soler González; Marta Ortega Bravo; Antonio Rodríguez Rosich; Plácido Santafe Soler; Eduard Peñascal Pujol; José Masamunt Jove; José Luis Morera Serra; Olga Pérez Queiruga; Antoni V. Plana Blanco

Merce Peri Viñes; Elisabeth Salsench Serrano; Eva María Oya Girona; Francisco Martín Luján; Rosa María Lara Ibáñez; Rafael Albiol Lluis; Ferrán Grifoll Ruiz; Irene Pascual Palacios; Dolores Gazol Soler

Manuel Carlos Salas Tomás; Rosario García Santafe; Nieves Gómez Moreno; Salvador Pertusa Martínez; Soledad García Bevia; Luis Richard Rodríguez; Alberto Asencio Aznar. Collaborator: María Adsuar Adán

José Vicente Herrero Ballestar; Beatriz Sánchez-Peral Sánchez; Amparo Antón Aguilera; M. José Manrique Costa; Manuel Batalla Sales; María Isabel Martí Giner; María Teresa Aguilar Arnau; M. Angeles Goterris Pinto; M. Dolores Aicart Fort; M. José Monedero

Fernando Quiles Añón; Juan Carlos Beguer Miquel; Asunción Girbes Revert; M. Angels Pages Juanola; María Teresa Villalba Calatayud; Amparo Castro Lorente

Macarena Candela Maestú; Juan José Dorado Martín; Antonio García Concellón; María S. Gil Llinás; Calixta Mantilla Calderón; Manuel Martínez de la Concha; Beatriz Pardo Díaz de Entresotos; Rosario T. Trinidad Ramos; José A. Morales Ruiz

Fernando Pérez Escanilla; Carlos Arjona Mateos; Dimas Igual Fraile; Amparo Gómez Espárrago; M. Socorro Gacto Fernández; José Polo García; Sebastián Traba Hernández; Sabina Rodríguez Borreguero; Alfonso Barquilla García

David Bouza Álvarez; Luis Buendía Fernández; Francisco Javier Maestro Saavedra; Manuel Barral Castro; Juan Manuel Peteiro Martínez; José Luis Díaz Santiago; Concepción Blanco Sánchez; Cristina Iglesias Díaz

Germán Fernández López; José Enrique Cajiao Bonome; José Manuel Menéndez Tamargo; Cristina Arijón Barazal; Vicente Quirós Madariaga; Domingo D. García Rivas; Domingo Fernández Méndez; M. Teresa García Novo; Bernardino Pardo Teijeiro

Rosario Calle Custodio; Alberto J. del Alamo Alonso; Pedro Blanco Iglesias; Antonio Pedreira Penedo; M. Dolores Antolín Novoa; Ana Veiga Vázquez; Agapito Diéguez Estévez; Jorge Lloveres Insua; Aida Robles Castiñeiras

Evangelina Filloy Miguez; José Carlos Sendín Sánchez; Xesús Fernández Núñez; Juan José Crespo Sabaris; José Rubio Panadeiros; M. Luisa Blázquez Ballesteros; Manuel Domínguez Sardiña; M. Begoña Porritt Lueiro; Manuel M. Lorenzo San Martín; Francisco López Sobrino

Natalia Feuerbach Achtel; Montserrat de la Torre Vidal; Alejandro Pizá Colom; Adriano Juan Mayrata Vicens; Cristina Gadea Ruiz; 
M. Antonia Viña Liste

Sta. Cruz de Tenerife

\section{La Rioja}

La Rioja

Community of Madrid

Region of Murcia

Chartered

Community of

Navarre

Navarre

Basque

Country
Álava

Maruja Bello Mora

Guipúzcoa Esther Recalde

Vizcaya Nekane Murga

Eizagaetxebarría
Catalina Picornell Yanes; Montserrat Sauleda Pares; Carmen López Moreno; Francisca Bestard Reus; Silvia Martín Delgado

Pedro J. Díaz Alayón; Luis Antonio Escalada Muñoz; Juan Pedro Jiménez Sarmiento; Beatriz Pérez López; Domingo Guerra Vega; Emilio Sánchez Carrión; Javier Santana Quilez; Gloria Calero González; Tomás González Rodríguez; Carmen Berrio Santana

Nicolás Maffiotte Carrillo; Juan Francisco Tejera Cabrera; Alfredo Bartolomé Andrés; Emma Navarro Brito; Francisco José Castro Álvarez

José Tomás Gómez Saenz; Juan Manuel Marrodan Adan; Julio Peña Angos; Alejandro Paradiñeiro Somoza; Jesús M. Gutiérrez de Bobadilla; José María Martínez Martínez; Ignacio Fernández Hurtado; Mikel Ugalde Olano; Juan José García Díaz; Oscar León Fernández

Antonio Sánchez Serrano; Belén Muñoz Gómez; M. José García Sacristán; Rocío Balas Urea; M. José Rojas Giraldo; Mar Noguerol Álvarez; Carlos Díaz Gómez-Calcerrada; Ignacio Arjona Anchoriz; Rocío Vello Cuadrado

María Xania de Casas Fernández; Rafael Luquín Martínez; Antonio Javier Llorens Minguell; M. del Carmen Paniagua Merchán; Concepción Carvajal Lucerga; Montserrat Martínez Sánchez; M. Isabel Caceres López; M. José Miras Martínez; Manuel Haenelt Maguel; Ana Celia Melgar García

Vicente Estremera Urabayen; Juan Manuel Pérez Gómez; Ramón Villanueva Moreno; M. Teresa Salinas Videndo; M. del Mar Hernández Espinosa; Carlos Figuero Echeverria; José Manuel Calleja Pascual; Arturo Erlanz Abad; Jesús Javier Jurio Burgui

Jon Azkarate Zubiaur; M. Asunción Aldecoa Eguillor; Juan Francisco Pérez de San Román Setien; Laura Ortiz de Lazcano Herrera; Lucia Pereda López; María Angeles Calvo Gainzarain; Olga Ruiz de Arbulo Ruiz de Alegría; Juan Carlos Martín

Fernández Landa; Luis Laborda González; Francisco Javier Blanco Cuadra

José Ramón Chopitea Gabiola; Aintzane Abasolo García; Miguel Mier Cascallana

Ana Isabel Izaguirre Berasategui; Juan Bautista Loizaga Horno; Cristina Lekube Angulo; José Angel Del Pozo Yruegas; Alazne Ramoneda Errazquin; Igone Asua Angulo; Epifanio Álvarez Grande; María Natividad de Soto Gorroño; Rosario Angulo Rivero

Electrocardiogram reading center

\begin{tabular}{|c|c|c|}
\hline Center & Coordinator & Other members of the group \\
\hline $\begin{array}{l}\text { Hospital Universitario de } \\
\text { Fuenlabrada (Madrid) }\end{array}$ & $\begin{array}{l}\text { Paula Awamleh } \\
\text { García }\end{array}$ & $\begin{array}{l}\text { Alejandro Curcio Ruigómez; Carmen Cristobal Valera; Adolfo Fontenla } \\
\text { Cerezuela; Catherine Graupner Abad; Rosa María Jiménez Hernández; } \\
\text { María Luaces Méndez; José María Serrano Antolín; Pedro Talavera } \\
\text { Sánchez; Rodrigo Teijeiro Mestre }\end{array}$ \\
\hline
\end{tabular}




\section{References}

1. A.S. Go, E.M. Hylek, K.A. Phillips, Y. Chang, L.E. Henault, J.V. Selby, et al. Prevalence of diagnosed atrial fibrillation in adults: national implications or rhythm management and stroke prevention: the AnTicoagulation and Risk Factors in Atrial Fibrillation (ATRIA) Study. JAMA, 285 (2001), pp. 2370-2375.

2. A. Majeed, K. Moser, K. Carroll. Trends in the prevalence and management of atrial fibrillation in general practice in England and Wales, 1994-1998: analysis of data from the general practice research database. Heart, 86 (2001), pp. 284-288.

3. W.B. Kannel, P.A. Wolf, E.J. Benjamin, D. Levy. Prevalence, incidence, prognosis, and predisposing conditions for atrial fibrillation: population-based estimates. Am J Cardiol, 82 (1998), pp. N2-N9.

4. W.B. Kannel, R.D. Abbott, D.D. Savage, P.M. McNamara. Epidemiologic features of chronic atrial fibrillation: the Framingham study. N Engl J Med, 306 (1982), pp. 1018-1022.

5. Y. Miyasaka, M.E. Barnes, R.C. Petersen, S.S. Cha, K.R. Bailey, B.J. Gersh, et al. Risk of dementia in stroke-free patients diagnosed with atrial fibrillation: data from a community-based cohort. Eur Heart J, 28 (2007), pp. 19621967.

6. P. Dorian, W. Jung, D. Newman, M. Paquette, K. Wood, G.M. Ayers, et al. The impairment of health-related quality of life in patients with intermittent atrial fibrillation: implications for the assessment of investigational therapy. J Am Coll Cardiol, 36 (2000), pp. 1303-1309.

7. S.E. Wolowacz, M. Samuel, V.K. Brennan, J.G. Jasso-Mosqueda, I.C. Van Gelder. The cost of illness of atrial fibrillation: a systematic review of the recent literature. Europace, 13 (2011), pp. 1375-1385.

8. J.M. García-Acuña, J.R. González-Juanatey, E. Alegría Ezquerra, I. González Maqueda, J.L. Listerri. La fibrilación auricular permanente en las enfermedades cardiovasculares en España. Estudio CARDIOTENS 1999. Rev Esp Cardiol, 55 (2002), pp. 943-952.

9. R. Masia, J. Sala, J. Marrugat, A. Pena, Investigadores del Estudio REGICOR. Prevalencia de fibrilación auricular en la provincia de Girona: el Estudio REGICOR. Rev Esp Cardiol, 54 (2001), p. 1240.

10. L. Cea-Calvo, J. Redón, J.V. Lozano, C. Fernández-Pérez, A. Martí-Canales, J.C. Llisterri, et al. Prevalencia de fibrilación auricular en la población española de 60 o más años de edad. Estudio PREV-ICTUS Rev Esp Cardiol, 60 (2007), pp. 616-624.

11. M.S. Labrador García, R. Merino Segovia, C. Jiménez Domínguez, Y. García Salvador, A. Segura Fragoso, C. Hernández Lanchas. Prevalencia de fibrilación auricular en pacientes > 65 años de un área de salud. Aten Primaria, 28 (2001), pp. 648-651.

12. R.L. McNamara, L.M. Brass, J.P. Drozda Jr., A.S. Go, J.L. Halperin, C.R. Kerr, et al. American College of Cardiology; American Heart Association. ACC/AHA key data elements and definitions for measuring the clinical management and outcomes of patients with atrial fibrillation: A report of the American College of Cardiology/American Heart Association Task Force on Clinical Data Standards (Writing Commitee to Develop Data Standards on Atrial Fibrillation). J Am Coll Cardiol, 44 (2004), pp. 475-495.

13. L.C. Silva. Diseño razonado de muestras y captación de datos para la investigación sanitaria. Díaz de Santos, Madrid (2000).

14. J.C. Deville, C.E. Särndal. Calibration estimators in survey sampling. J Am Statist Assoc, 87 (1992), pp. 376382.

15. M. Schmutz, S. Beer-Borst, A. Meiltz, P. Urban, J.M. Gaspoz, M.C. Costanza, et al. Low prevalence of atrial fibrillation in asymptomatic adults in Geneva, Switzerland. Europace, 12 (2010), pp. 475-481.

16. N.M. Wheeldon, D.I. Tayler, E. Anagnostou, D. Cook, C. Wales, G.D.G. Oakley. Screening for atrial fibrillation in primary care. Heart, 79 (1998), pp. 50-55.

17. J. Heeringa, D.A. Van der Kuip, A. Hofman, J.A. Kors, G. Van Herpen, B.H. Stricker, et al. Prevalence, incidence and lifetime risk of atrial fibrillation: the Rotterdam study. Eur Heart J, 27 (2006), pp. 949-953.

18. F.D.R. Hobbs, D.A. Fitzmaurice, S. Jowet, S. Mant, E. Murray, S. Bryan, et al. A randomized controlled trial and cost-effectiveness study of systematic screening (targeted and total population screening) versus routine practice for the detection of atrial fibrillation in people aged 65 and over. The SAFE study. Health Technol Assess, 9 (2005), pp. 1-74.

19. P.T. Önundarson, G. Thorgeirsson, E. Jonmundsson, N. Sigfusson, T. Hardarson. Chronic atrial fibrillationepidemiologic features and 14 year follow-up: a case control study. Eur Heart J, 8 (1987), pp. 521-527.

20. V. Barrios, A. Calderón, C. Escobar, M. De la Figuera. Grupo de Atención Primaria de la Sección de Cardiología Clínica de la Sociedad Española de Cardiología. Pacientes con fibrilación auricular en Atención Primaria. Estudio Val-FAAP. Rev Esp Cardiol, 65 (2012), pp. 47-53.

21. J.R. Banegas, E. López-García, J. Dallongeville, E. Guallar, J.P. Halcox, C. Borghi, et al. Achievement of treatment goals for primary prevention of cardiovascular disease in clinical practice across Europe: the EURIKA study. Eur Heart J, 32 (2011), pp. 2143-2152.

22. M.W. Reynolds, K. Fahrbach, O. Hauch, G. Wygant, R. Estok, C. Cella, et al. Warfarin anticoagulation and outcomes in patients with atrial fibrillation: a systematic review and metaanalysis. Chest, 126 (2004), pp. 19381945.

23. Atrial Fibrillation Investigators. Risk factors for stroke and efficacy of antithrombotic therapy in atrial fibrillation. Analysis of pooled data from five randomised controlled trials. Arch Intern Med, 154 (1994), pp. 1449-1457.

24. K.L. Furie, L.B. Goldstein, G.W. Albers, P. Khatri, R. Neyens, M.P. Turakhia, et al. Oral antithrombotic agents for the prevention of stroke in non valvular atrial fibrillation: a science advisory for healthcare professionals from the American Heart Association/American Stroke Association. Stroke, 43 (2012), pp. 3442-3453. 